\title{
Early Childhood Education and Instructional Ecology: A Vygotskian Approach in Teaching Early Childhood Social Studies
}

\author{
By Kwabena Ofori-Attah ${ }^{*}$
}

\begin{abstract}
This study guided by Vygotsky's Zone of Proximal Development (ZPD) theory explored the perception of pre-service teachers about the application of the ZPD in the classroom. Five participants, all junior students, were purposefully selected from a university in the southern region of the United States to participate in the study. Open-ended interview questions were designed from a review of the literature regarding the effectiveness of Vygotsky's ZPD in the classroom. Axial coding was used to analyze the data for the final research report. A major finding from the study is that Vygotsky's ZPD is recognized by Educator Preparatory Providers (EPPS) as a major instructional approach used to promote student achievement and that some pre-educator candidates perceive problems implementing this innovative form of teaching social studies in the early childhood classroom. Another significant finding from the study is that it extends our knowledge about the application of Vygotsky's ZPD in the early childhood social studies classroom. Implications for early childhood teacher preparation and future research are considered in the paper.
\end{abstract}

Keywords: cognitive development, early childhood education, instructional ecology, preservice teachers, zone of proximal development

\section{Background of the Study}

The education of children during the early years of learning, from birth to age five, within the appropriate instructional ecology has attracted the attention of educators in recent years. A trend that started slowly during the middle ages has now become a top agenda in perhaps many sectors of teacher education programs. All educator preparation providers (EPPs) are expected by accreditation agencies such as the Council for the Accreditation of Teacher Preparation (CAEP) to prepare teachers who have the content, pedagogical and professional knowledge to be effective teachers in the classroom (Essa, 2011; Snowman \& McCown, 2015).

Dating back to antiquity, most parents did not neglect the education of their children. For instance, the ancient Greeks, Romans, Egyptians, Chinese, Indians, all paid attention to the education of young children. The ancient Greeks saw human development as a transformation from an imperfect state of childhood to the ideal adulthood (Essa, 2011). Therefore, they had education systems for both boys and girls (Essa, 2011). The ancient Romans set up schools called ludi to educate young children, especially boys. Other ancient societies paid more attention to the education of young boys more than the education of young girls.

\footnotetext{
*Associate Professor of Education, Central State University, USA.
} 
Young girls had their education essentially at home (Kaplan, \& Owings, 2011; Ornstein \& Levine, 2006). These observations clearly indicate that the education of young children in ancient societies attracted the attention of educational planners.

In colonial America, teachers employed to teach young children had little or no training in pedagogical skills. The instructional ecology was ill-planned and delivered. Essentially, the teachers taught the way they were taught when they were young children in school. In the classroom, these untrained teachers relied on their own effort and thinking skills to teach these young children. Such practices denied many young children the opportunity to academically develop to their fullest potential. Today, the education of young children has attracted the attention of educational planners and so teachers who plan to teach young children in the United States of America must attend college to earn a teaching certificate before being employed to teach young children in the public schools (Essa, 2011; Morrison, 2012; Slavin, 2015).

Apart from training early childhood teacher candidates on how to acquire pedagogical skills, educator preparation institutions provide these teacher candidates intellectual groundings and foundations in the content areas (Fritzer, \& Brewer, 2010). To be specific, the traditional social studies curriculum at the kindergarten grade level focuses on content that teaches about groups of people in terms of current affairs, economics, geography, history, international and global issues (Farris, 2015; Sanchez, 2010; Seefeldt, Castle, \& Falconer, 2014; Zarrillo, 2012).

\section{Problem Statement}

Instructional ecology is an essential part of pedagogy. It is important for teachers to master instructional ecology because it forms the foundation for effective teaching. Instructional ecology is the relationship between students and their instructional environment (Ysseldyke, 2004). As Ysseldyke (2004, p. 2080) argues, "Students' behavior and academic performance are influenced by the environment in which they are taught." Because of this argument, all educator preparation programs include pedagogical strategies that are based on sound educational theories, principles, or models (Seefeldt, Castle, \& Falconer 2014; Shabani, 2016). For more than 100 years, psychologists have developed methods for teaching and learning and, within the past few decades, have focused significant attention on studying educationally relevant theories and aspects of learning with the sole aim of improving student learning (Larson \& Keiper, 2011; Mayer, 2003; Tuckman \& Monetti, 2013). Some of the common educational theories covered in teacher education programs include behaviorism, cognitive psychology, social cognitive learning, human development, or Vygotsky's Zone of Proximal Development (ZPD). The ZPD is the gap between the child's independent performance and the child's assisted performance from and an adult or a more expert peer (Schickedanz, Schickedanz, Forsyth, \& Forsyth, 2001). All these theories embody elements of instructional ecology. Consequently, all teacher 
candidates study these theories during their training (Shabani, 2016). They study these theories during their pedagogical courses. However, some teacher candidates in the early childhood education program anticipate encountering problems implementing Vygotsky's ZPD in their teaching after graduation. Despite an increased interest in the integration of educational theories and the appropriate instructional ecology in the preparation of teacher candidates by educator preparation providers (EPPs), there are currently no empirical studies on how teacher candidates in the social studies early childhood program perceive their readiness to apply Vygotsky's ZPD into their teaching after graduation. Some of the previous studies focus on the application of ZPD to the teaching of mathematics (Sophian, 2013), and others also focus their research with the ZPD on language acquisition (Rueda \& Yaden, 2013). This study intends to fill the gap in our knowledge about how some preservice teacher candidates perceive their readiness to apply the ZPD in teaching early childhood social studies after graduation.

\section{Purpose Statement}

Vygotsky's ideas about learning promote cognitive development especially in young learners (Larson \& Keiper, 2011; Tuckman, \& Monetti, 2013). The purpose of this study was to explore the perception of early childhood preservice teacher candidates about their readiness to apply Vygotsky's ZPD in the classroom to promote effective teaching and learning after graduation. Vygotsky's ZPD has become a key concept in teacher pedagogical training because of its promise to promote effective and efficient instructional practices in the classroom.

\section{Conceptual Framework}

According to Marzano and Brown (2009, p. 10), teaching is both an art and science guided by certain principles, rules, and theories (Muth \& Alvermann, 1999; Ornstein \& Sinatra, 2005; Snowman \& McCown, 2015). This argument is supported by others such as Arends (2009, p. 2), and Moore (1999, p. 44). Arends points out that teaching is a science because its practices are based on research and scientific evidence (p. 4). Arends contends further that, teaching is an art because it is based on the teacher's experiences and the wisdom of practice (p. 4). Marzano and Brown (2009, p. 1) argue teaching is "art in the sense that it involves no specific script all effective teachers must follow”. Marzano and Brown $(2009$, p. 1) argue further that teaching "is science in the sense that there are strategies that research over time has shown to have a high probability of enhancing student achievement". Effective teaching does not just happen. It is always the result of careful planning, presentation, and assessment. Knowledge construction, according to the extant literature promotes meaningful learning (Berger, \& Luckmann, 1991; Bodrova, 1997; Henson, 2004; Snowman \& McCown, 2015). Knowledge construction or the acquisition of knowledge has for many years been 
the subject for debate and research. The ancient Egyptians, Greeks, Romans, all postulated about the appropriate ways for teaching students to acquire knowledge (Essa, 2011; Powell, 2009).

Cognitive development or knowledge construction is the primary focus of teaching and learning (Powell, 2009; Schickedanz, Schickedanz, Forsyth, \& Forsyth, 2001). Constructivist "view learning as a process not just of acquiring information but of creating new understanding" (Henson, 2004, p. 13.). Although Piaget and other constructivist thinkers such as Locke, Rousseau, Pestalozzi, Johann Herbart, and Dewey have long made significant contributions to the field of knowledge construction, the search for the appropriate learning ecology continues unabated (Goodman, 2000; Henson, 2004). The contributions from these constructivists have always been a subject for debate. According to Vygotsky (1986), "all knowledge, from the most important to the most mundane, is socially constructed" (as cited in Schickedanz, Schickedanz, Forsyth, \& Forsyth, 2001, p. 21). What makes Vygotsky's ZPD to knowledge construction is that it "described the transformation of simple perception, involuntary attention, and simple memory into categorical perception, conceptual thinking, logical memory, and selfregulated attention" (Gredler, 2001, p. 297). The constructivist revolution has brought new conceptions of learning and teaching (Marginson \& Dang, 2017; Susan, 2003). Although constructivism takes many forms, an underlying premise is that learning is an active process in which learners become active sense makers who seek to build coherent and organized knowledge (Henson, 2004; Mayer, 2004).

Learning in the classroom involves the interactions between teachers and students or between students and students. Which of these two is the most productive? According to Vygotsky, children have a specific range or zone within which they can learn efficiently (Maxim, 2010). One zone he describes as the Zone of Actual Development (ZAD) and the other the Zone of Proximal Development (ZPD). The ZAD is the range where students can accomplish tasks on their own without the help of others. When children can solve problems or successfully accomplish tasks based upon their own efforts, we affirm that the task was within their Zone of Actual Development (ZAP). In the ZPD on the other hand, students can only solve problems or accomplish tasks only with the help of significant others or adults who have knowledge about the task in hand. It is in light of this observation that the ideas of Vygotsky's ZPD about knowledge construction have attracted the attention of educators in recent years.

As John-Steiner and Mahn, (1996, p. 191-192) have pointed out:

At a time when psychologists were intent on developing simple explanations of human behavior, Vygotsky developed a rich, multifaceted theory through which he examined a range of subjects including the psychology of art; language and thought; and learning and development, including a focus on the education of students with special needs.

Vygotsky's (1986) thinking indicates that the origin of knowledge construction should not be sought in the mind but in the social interaction co- 
constructed between a more and a less knowledgeable individual (Bodrova, 1997; Lantolf, 2008; Muth \& Alvermann, 1999; Ornstein \& Sinatra, 2005).

Moreover, the construction of knowledge is a sociocultural process impacted by environmental factors such as peers, teachers, and other knowledgeable people in the immediate environment of the individual. affected by the physical and psychological tools and artifacts (Glassman, 2001; Goodman, 2000; Lantolf, 2004).

Vygotsky (1986) developed the theory of ZPD in a critique of the use of Intelligence Quotients (IQ) tests as a form of assessing students. According to Vygotsky, the child with a large ZPD will do much better in school because this measure gives a more helpful clue than mental age does to the dynamics of intellectual progress (Vygotsky, 1986). Vygotsky further argued that children learn with confidence when they are supported by a more knowledgeable person because such positive interactions bring out the specifically human qualities of the mind and lead the child to new developmental levels (Vygotsky, 1986, p. 188, see Figure 1).

Vygotsky's ZPD provides children the avenue to exhibit their learning styles. It is common knowledge that human beings differ in the way they learn. Some learn best by listening (auditory), some learn by looking (visual), some by touching (tactile), and some by performing an action (kinesthetic) (Lerner, 2006, p. 238; Slavin, 2015, p. 93). When providing support for a child within the ZPD, teachers are able to identify appropriate learning styles to apply effective learning and teaching strategies to help the child learn how to learn to become learners.

According to Seefeldt, Castle, and Falconer (2014, p. 11) Vygotsky's knowledge construction approach includes the following:

- A person's social and psychological worlds are constructed.

- Child-adults interaction is important for cognitive development.

- The capacity to use language to regulate thought and action is distinctly human and the source of the conscious mental life.

- Social experience is extremely important for cognitive growth.

- Education leads to development.

- Teaching must be geared to the zone of proximal development; that is, it must match what it is to be taught to what the child already knows and will be able to accomplish with adult help until it can be accomplished independently.

The integration of behavior and consciousness or the unification of mind and social interaction is a major characteristic of Vygotsky's developmental theories because it defines precisely what constitutes human development and knowledge construction (Bodrova, 1997; Schickedanz, Schickedanz, Forsyth, \& Forsyth, 2001; Shabani, 2016).

Vygotsky (1986) stressed that language development is the key to knowledge construction. As observed by Schickedanz, Schickedanz, Forsyth, \& Forsyth (2001, p. 22): 
The cultural-historical aspect of Vygotsky's theory states that these important linguistics structures, thoughts, and ways of thinking are not developed independently by each child but are instead the product of a long line of individual children's interactions with more advanced members of their culture.

Figure 1. Vygotsky's Zone of Proximal Development

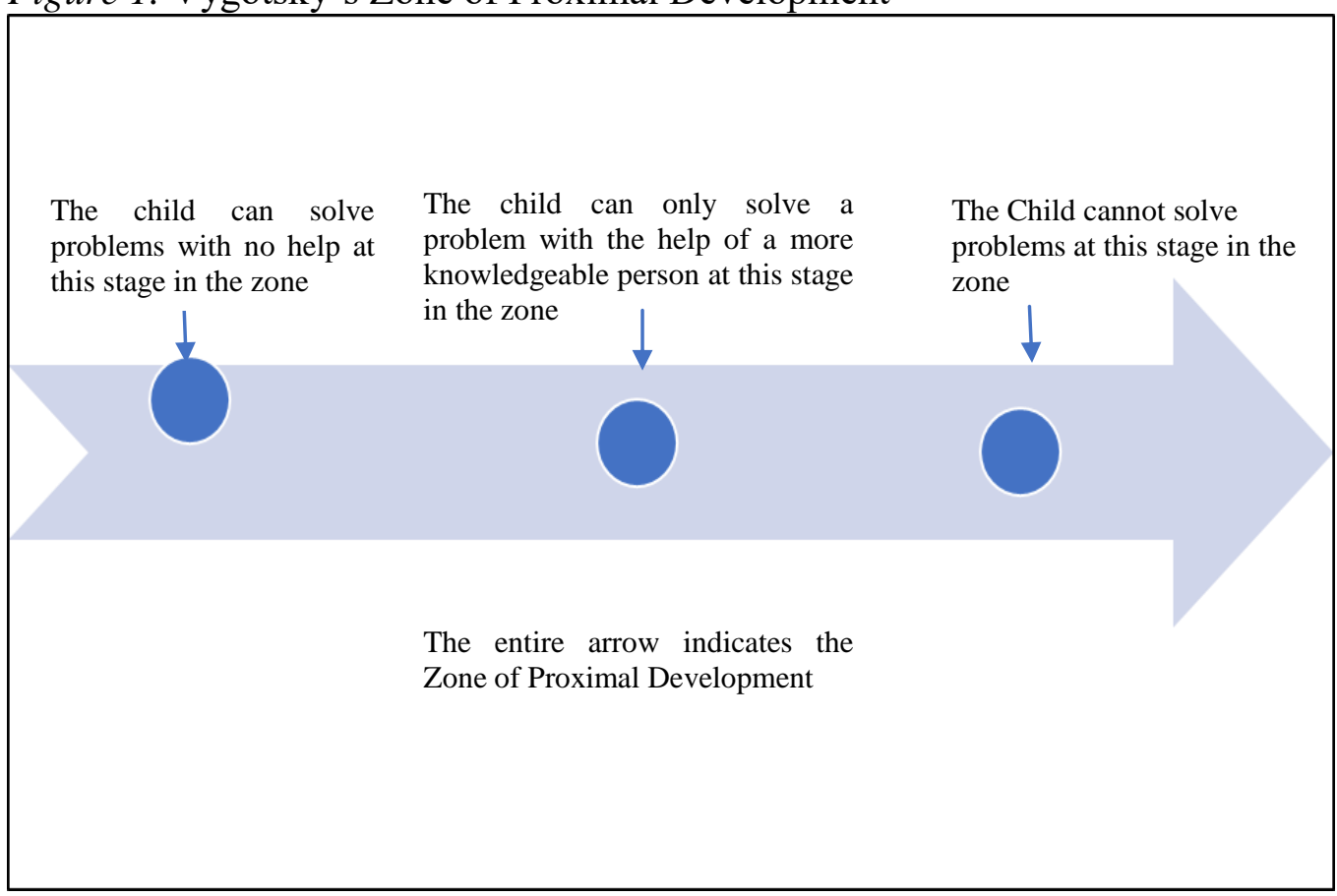

\section{Significance of the Study}

This study focused on one major theory, the ZPD as developed by Vygotsky (1986), the Russian educator and psychologist, to shed light on teacher preparation by an EPP. Vygotsky's ideas about knowledge construction have become part of teacher preparation because of its promise to provide learners the foundation blocks for critical thinking to provide them the means to take ownership of their learning (Henson, 2004; Mayer 2004; Tuckman \& Monetti, 2013).

The ideas of Vygotsky (1986) were suppressed by the Soviet government because his methods were not deemed rigorous or "radical" enough to spark revolutionary tendencies in the learner, especially young children (Schickedanz, Schickedanz, Forsyth, \& Forsyth, 2001; Susan, 2003; Marginson \& Dang, 2017). However, Vygotsky's ideas about cognitive development have become a new approach to the principles of teaching and learning because of its propensity to promote intellectual development in a learner (Cox, 2008; Maxim, 2010). As noted by Larson and Keiper (2011, p. 92):

Current thinking about the ideas tied to Vygotsky's ZPD theory has led to such terms as scaffolding, constructivism, and hands-on learning. These imply that learning occurs when some additional source provides a support 
network to promote learning (e.g. in the same way that a scaffold provides support for a building.

The findings from this study will also add to our growing body of knowledge about how to create developmentally appropriate instructional ecology for the education of children, especially those in the early childhood classes (Snider \& Fu, 1990). The difficulty level of material is an extremely important consideration when teaching, especially young children (Lerner, 2006).

Creating the developmentally appropriate instructional ecology is important in the education of children, especially young ones. When Helen Keller's teacher, Annie Sullivan, created the appropriate instructional ecology, she was able to teach Helen Keller, a blind and dumb student to read and write (Davidson, 1965). Research indicates that providing children with minimal support during instruction is not enough to help them positively engage in the lesson. Several reviews of empirical studies have established a solid research-based case against the use of instruction with minimal guidance (Kirschner, Sweller, \& Clark, 2006). Mayer (2004) reviewed over 50 articles written about instructional strategies and concluded from the study that knowledge construction such as recommended by Vygotsky's ZPD, especially for young children, is the preferred choice by many educators.

As constructivism has become the dominant view of how students learn, it is very important that EPPs find empirical-based research to refine the curriculum for teacher preparation (Mayer, 2004). The proposed study builds on literature written about learning theories and the quest for developmentally appropriate practice in the early childhood classroom, approximately from infancy to the third grade or age 8 (Driscoll, \& Nagel, 2008; Essa, 2011; Morrison, 2012). Moreover, empirical research such as this one exploring the perception of preservice teacher candidates about the process for implementing the ZPD is likely to support and promote the professional development of early childhood teachers (Driscoll \& Nagel, 2008; Essa, 2011; Morrison, 2012; Snider \& Fu, 1990).

\section{Research Questions}

As already pointed out, the main purpose of this study is to explore the perception of early childhood teacher candidates about their readiness to apply Vygotsky's ZPD in the early childhood social studies classroom after graduation. Exploring and examining these perceptions is likely to help educators lay a solid foundation for the application of Vygotsky's ideas in teaching social studies to young children (Seefeldt, Castle, \& Falconer, 2014).

The following research questions were formulated based upon the extant literature on developmentally appropriate instructional approaches for early childhood education:

1. How do teacher candidates perceive the integration of Vygotsky's Zone of Proximal Development in the curriculum? 
2. What problems do the pre-service teachers anticipate implementing the Zone of Proximal Development in their teaching after graduation?

3. What skills has their teacher education program equipped them to implement the Zone of Proximal Development in their teaching after graduation?

4. How do these pre-service teachers plan to learn more about the Zone of Proximal Development?

\section{Methods}

\section{Design and Procedure}

This was a qualitative case study designed to explore the perception of preservice teachers about the integration of Vygotsky's ZPD into teaching social studies in the early childhood classroom. The qualitative approach was preferred to other research methods because qualitative approach to the study of social phenomena provides the researcher the opportunity to suggest grounded propositions, provide explanations to extend the understanding of phenomena, or promote opportunities for informed social action (Creswell, 2014; McMillan \& Schumacher, 2006; Ravitch \& Carl, 2016).

The primary data for the study were collected through interviews and document analysis, such as information in textbooks, the Internet, and journal articles on curriculum development such as early childhood education. Five students in a Southern University in the United States were conveniently selected to participate in the study. Convenience sampling method was used because the opinion of these five preservice social studies was considered more valuable than those that would be obtained in a random sample of all the students in the teacher education program (White \& McBurney, 2013).

The College of Education has a small teacher education department with only about 30 teacher candidates. These teacher candidates were specializing in different areas of study. Five specialized in Integrated Mathematics, 3 specialized in Integrated Science Education, 11 specialized in Physical Education, 6 specialized in Music and 5 others specialized in Early Childhood Education. In order to increase the sample size for the study, all the five teacher candidates specializing in the Early Childhood Education program were conveniently selected to participate in the study. All five teacher candidates had completed a course in social studies pedagogy. Of the five students selected to participate in the study, three were male students and two were female students. One of the three male students was a Caucasian, the second was an Asian student and the third an African American student. Both female students were Caucasian. All the participants were junior students and had completed several educational theories such as behaviorism, social cognitive learning, information processing theories, theories of human development, multiple intelligence theory, theories of social and emotional development, and Vygotsky's Zone of Proximal Development (Driscoll \& Nagel, 2008; Essa, 2011; Woolfolk, 2007). 
Table 1. Demographics of the Participants

\begin{tabular}{|l|c|c|c|c|c|}
\hline $\begin{array}{l}\text { Name } \\
\text { (Synonym) }\end{array}$ & Race & Age & Gender & $\begin{array}{c}\text { Student } \\
\text { Status }\end{array}$ & $\begin{array}{c}\text { Early Childhood } \\
\text { Education (ECE) } \\
\text { Methods/Pedagogy Social } \\
\text { Studies Course Completed }\end{array}$ \\
\hline Maria & Caucasian & 28 & Female & Junior & Yes \\
\hline Akua & Caucasian & 25 & Female & Junior & Yes \\
\hline Abu & $\begin{array}{c}\text { African } \\
\text { American }\end{array}$ & 28 & Male & Junior & Yes \\
\hline Krishna & Asian & 30 & Male & Junior & Yes \\
\hline Mark & Caucasian & 25 & Male & Junior & Yes \\
\hline
\end{tabular}

All these preservice teacher candidates were conveniently selected to participate in the study because as part of their teacher education program, they were expected to integrate educational theories, models, or concepts into their teaching. During the field experience component of their teacher preparation, each student used the ZPD method to teach young children social studies lessons. In effect, they were expected by their university supervisors to be innovative in the classroom and not to teach the way they were taught when they were toddlers or young children.

\section{Interview}

Open-ended interviews were used to collect the data for this qualitative study. Each student was interviewed for about 30 minutes with the same questions in the same order but different follow up questions in order to probe for consistent responses (Best \& Khan, 2006). In any given interview situation, some participants tend to include probes in their responses. Such probes tend to prolong the time for the interview and stretch the interview beyond the original scope for the study. These probes constitute what Webb, Campbell, Schwartz, and Sechrest, (1966) call the dross rate. Again, as observed by McMillan and Schumacher (2006), "Qualitative in-depth interviews are noted more for their probes and pauses" (p. 353) and so the participants were given enough time to elaborate on their responses (Best \& Khan, 2006; Rubin \& Rubin, 2012).

However, to cut down on dross rate, the participants who tended to dwell further on issues or engaged in continuous, or elaborate probes were quickly but politely reminded to focus on ideas that were germane to the study. Through such interview strategies, the participants were encouraged to focus their responses on concepts or ideas that had the promise of yielding the appropriate data for the study (Johnson, 1975; Ravitch \& Carl, 2016; Webb, Campbell, Schwartz, \& Sechrest, 1966).

One of the interview questions was this: "What problems do you anticipate implementing the ZPD in your teaching after graduation?" Another interview question was this: "How do you plan to overcome the difficulties that you perceive in implementing the ZPD in the classroom after your graduation?" 


\section{Archival Records}

Other sources for the data collection included internet sources, books, journal articles, and magazines. These sources were used to provide further evidence to support the information from the participants (Salkind, 2012). Content analysis or extraction of data from archival sources provides unobtrusive measures when studying phenomenon (Webb, Campbell, Schwartz, \& Sechrest, 1966). These unobtrusive measures provide information that sheds further light on the responses to the research questions without further interference from the respondents, although this might constitute using someone else's filter for the study (Ravitch \& Carl, 2016; Webb, Campbell, Schwartz, \& Sechrest, 1966).

\section{Data Analysis}

Before any meaningful data analysis could be performed, I had to reduce the lengthy information from my participants into manageable chunks of information. Some of the major codes that emerged from the interviews included "lack of resources, time, classroom procedures, classroom arrangements, learning rates, learning styles, class size, attention span, critical thinking, knowledge construction, and ownership of learning." Open, axial, and selective coding were used to categorize the data into themes for the study. Similar ideas were placed into broad categories and later into separate themes as recommended by Ravitch and Car (2016), Ary, Jacobs, Sorensen, and Walker (2014), Creswell (2014). In some cases, multiple codes were assigned to a particular category in order to close all the gaps in the data analysis.

Ravitch and Car (2016, p. 251) recommendations were used as the foundation for creating the codes. Therefore, the approach for creating the codes included checking or looking for:

- Repetition in and across various data items

- Strong or emotive language

- Agreement between individuals

- Concepts that are not discussed or commented on

- Disagreement between individuals

- Mistakes and how/if they are solved

Finally, code definitions and data displays were used to develop themes to draw conclusions for the final report (see Table 2). 
Table 2. Data Display for Analysis

\begin{tabular}{|c|c|c|}
\hline Code Sets & Categories & Research Questions \\
\hline $\begin{array}{l}\text { Classroom Procedures, } \\
\text { Motivation, Teaching Tools, } \\
\text { Student Behavior } \\
\text { Seating Arrangements }\end{array}$ & $\begin{array}{c}\text { Classroom } \\
\text { Management }\end{array}$ & $\begin{array}{l}\text { How do you plan to overcome the } \\
\text { difficulties that you perceive in } \\
\text { implementing the ZPD in the } \\
\text { classroom after your graduation? }\end{array}$ \\
\hline $\begin{array}{l}\text { Learning Styles, Learning Rate, } \\
\text { Grouping, Asking Questions, } \\
\text { Modeling, Guided Practice, } \\
\text { Feedback, Concepts } \\
\text { Scaffolding }\end{array}$ & Pedagogy & $\begin{array}{l}\text { How do you plan to overcome the } \\
\text { difficulties that you perceive in } \\
\text { implementing the ZPD in the } \\
\text { classroom after your graduation? } \\
\text { How do you perceive the } \\
\text { integration of the ZPD in the } \\
\text { curriculum? } \\
\text { How do you plan to learn more } \\
\text { about the use of ZPD in the } \\
\text { classroom? }\end{array}$ \\
\hline $\begin{array}{l}\text { Knowledge Construction, } \\
\text { Grouping, Critical Thinking, } \\
\text { Student Achievement } \\
\text { Professional Development } \\
\text { Technology } \\
\text { Cooperative Learning }\end{array}$ & $\begin{array}{c}\text { Student } \\
\text { Learning }\end{array}$ & $\begin{array}{l}\text { How do you plan to learn more } \\
\text { about the use of ZPD in the } \\
\text { classroom? } \\
\text { What teaching skills did your } \\
\text { pedagogy course provide you } \\
\text { with teaching young children? } \\
\text { How do you understand the ZPD } \\
\text { as developed by Vygotsky? }\end{array}$ \\
\hline $\begin{array}{l}\text { Class Size, Technology, } \\
\text { Teacher Assistant } \\
\text { Student Behavior } \\
\text { Time, Cognitive Development } \\
\text { Scaffolding }\end{array}$ & Problems & $\begin{array}{l}\text { What problems do you anticipate } \\
\text { implementing the ZPD in your } \\
\text { teaching after graduation? }\end{array}$ \\
\hline $\begin{array}{l}\text { Learning Styles, Critical } \\
\text { Thinking, Grouping, Hands-on- } \\
\text { Learning, Scaffolding } \\
\text { Constructivism } \\
\text { Technology, YouTube }\end{array}$ & $\begin{array}{l}\text { Knowledge } \\
\text { Construction }\end{array}$ & $\begin{array}{l}\text { How do you understand the ZPD } \\
\text { as developed by Vygotsky? } \\
\text { How do you plan to use the ZPD } \\
\text { when teaching social studies to } \\
\text { young children? } \\
\text { How do you plan to learn more } \\
\text { about the use of ZPD in the } \\
\text { classroom? }\end{array}$ \\
\hline
\end{tabular}

\section{Results}

The results of this study will be discussed within the conceptual framework and the guiding research questions. One major problem with qualitative study is the task of making sense of the volume of data that emerge from interviewing 
participants. Sometimes the information is so large and voluminous that the researcher must sift through notes upon notes, data upon data in order to craft a report that meets the expected outcome for the study. This study did not avoid this qualitative tradition. The research questions guided the study and eventually became the major coding categories. In the following section, the most interesting themes that emerged from the interviews will be presented.

\section{The Integration of Vygotsky's Zone of Proximal Development in the Curriculum}

Vygotsky's Zone of Proximal Development deals essentially providing instructional support and assistance to learners from multiple perspectives. It implies working and supporting the thinking, reasoning and logical thinking of students to arrive at the desired outcomes of the instructional process. Each preservice teacher candidate had no problem providing a positive response to this question: "How do teacher candidates perceive the integration of Vygotsky's Zone of Proximal Development in the curriculum?" Akua, a Caucasian female preservice teacher candidate, had this to say, "The integration of Vygotsky's ZPD in the classroom is something we do all the time. In the methods courses, we are always instructed to be supportive of the effort's kids make to make sense of what they learn. Guided practice, grouping, or scaffolding are all the teaching strategies that we are asked to use to help kids master content. Kids at this stage need the support of teachers to make sense of what they learn in the classroom."

Abu, an African American male student, did not find it hard adding his voice to this question. From Abu's point of view, the integration of the ZPD in the curriculum is appropriate for all children especially kids who are beginning to learn new things and concepts to build a scholarship of reading, writing, and computations. "At the early grades, one approach I find effective is using convergent questions to assess student learning. When I use this approach, I get the opportunity to assess what most of the students have learned about key concepts being taught" Abu added.

"Every curriculum that tends to promote effective instruction in the early grades uses the ZPD to help kids master essential concepts. Kids in the early stages need to be scaffolded to master the art of reading, writing, computing, and communicating." These were the words that Krishna, an Asian student who appeared to be the oldest student in the class added to the conversation.

\section{Problems Pre-Service Teachers Anticipate Implementing the ZPD in their Classroom after Graduation}

The students provided dismal responses to the research question about the problems they anticipated implementing the ZPD in their classroom after graduation. The research question was this: What problems do you anticipate implementing the Zone of Proximal Development in your teaching after graduation? All five preservice teachers provided similar responses. These were listed as follows: 
- Class Size,

- Technology,

- Teacher Assistant,

- Student Behavior,

- Time.

All the pre-service teacher candidates opined that a large class size of say, 15, 20, 25 would impede the smooth implementation of the ZPD in the classroom. Maria added even a class size of 10 with a limited amount of time, supplies, and different learning rates and styles would make the implementation difficult. "I remember in the school where I did my field experience, some of the kids had behavioral problems and therefore I found it very difficult implementing my lesson. I was lucky the cooperating was close by to offer me the help I needed to keep the class focused on what I was teaching them" she added.

Mark, a Caucasian male student also echoed similar sentiments about the problems he anticipated facing implementing the ZPD in his classroom after graduating. "Some of the kids in my second-grade class during my field experience were perhaps not used to taking turns using materials. Instructional materials were not enough for all the students to be doing the same thing at the same time. There was, therefore, the need for some of the students to take turns using such materials in learning. However, some of the students violated the rules of taking turns and often snatched specific crayon colors from their mates."

Maria was quick to observe that during her field experience, the cooperating teacher often gave her a maximum of five students to teach. "When my supervision teacher came to observe me, I had no problem managing my class. I was able to provide the students-one-on- support to master the material I was teaching them. The supervisor was impressed with my work." Maria added, "I could not have achieved this feat if the class size was more than 10 "

\section{Teaching Skills the Pre-Service Teachers Have Been Taught to use to Implement the ZPD in the Early Childhood Classroom}

Vygotsky's Zone of Proximal Development (ZPD) is about providing scaffolding for children to learn. Scaffolding occurs when adults or more experienced persons model what must be learned to the child and then support the child to do the same. The application of scaffolding differs from grade level to grade level. This implies that teachers or adults guiding children to learn new tasks in the classroom must design the learning task to meet the cognitive development of the children. The following teaching strategies are what emerged from the interview with the preservice teachers as the appropriate strategies for implementing the ZPD in the early childhood social studies classroom:

- Modeling,

- Guided practice or guided discovery,

- Application practice,

- Grouping,

- Tutoring. 
With modeling, Abu said that teachers take the lead in modeling or practically demonstrating the correct way for mastering a skill or learning the meaning of concepts, historical events, writing, reading, or speaking. "Teachers can model the correct way of doing things to kids in almost all situations. The best way to model the appropriate behavior is to use a step by step approach while modeling the correct way or procedure for mastering the learning task or event to students". Maria, Krishna, and Akua all added that after the modeling comes the guided practice or guided discovery phase. During the guided practice phase, teachers provide immediate responses and specific feedback to the kids. Krishna added "During the guided practice phase, the teachers should pay close attention to what the kid does. The main role of the teacher should be a guide by the side of the student."

Maria added that during the guided practice phase, "it is ok for teachers sometimes to physically intervene or implement direct instruction approach and then leave the student to master the task on his/her own."

In order to find out what the kids have learned, it is often desirable to assign students tasks that will provide them the opportunity to apply what they have learned with the help of the teacher in a new situation. This is the implication of their responses.

On grouping, the pre-service teachers observed that grouping kids without the presence of an adult often leads to chaotic situations in the classroom. Akua said "Kids are not matured enough to know the benefit of working under a leader who appears to be of the same age or at cognitive level with them. Therefore, for grouping as a teaching strategy to work, the kids need to work with an adult such as the teaching assistant as the group leader." Abu added that he will not use grouping as an instructional strategy in the early childhood classroom to implement ZPD because it is likely to obscure or mar the instructional ecology. "I would rather use whole-class instructional approach to implement the ZPD in my social studies early childhood classroom through the process of modeling, guided practice and application practice."

Although tutoring is not usually the preferred method of implementing the ZPD in the social studies early childhood classroom, the preservice teachers did not rule out this option when necessary. All five preservice teachers agreed that tutoring is the most effective way to help struggling students to master content, especially for those students whose learning rate is below the grade level. The extant literature supports this point of view. This is because tutoring has the potential to provide slower learners the means to organize their thoughts and reasoning abilities to arrive at logical conclusions (Ornstein, \& Sinatra, 2005).

\section{Planning to Learn More about the Zone of Proximal Development}

The main question asked was this: "How do you plan to learn more about the Zone of Proximal Development?"

Professional development was the first means the pre-service teachers identified. Through professional development, the students hoped to learn more about Vygotsky's ZPD. The students were not specific about the type of 
professional development that they thought would help them. When I probed further $\mathrm{Abu}$ and Maria identified workshops on pedagogy as the type of professional development that would help them keep abreast with their pedagogical practices including mastering the ZPD. Maria, Krishna, and Akua mentioned apart from professional development on pedagogy conference, they planned to search YouTube or Teacher Tube for videos on student engagement in the classroom.

Another route some of them mentioned was enrolling in a graduate program in teacher education. "Graduate program in curriculum and instruction, with a concentration in early childhood education, will provide me the opportunity to learn more about ZPD" was the prolonged response from Maria, when pressed to be more specific about her plans to expand her knowledge about Vygotsky's ZPD.

Mark also indicated that he will read magazines on teaching and learning or books on teaching and learning to broaden his outlook on the implementation of the ZPD in the classroom. He added that "the Internet is another source where teachers are capable of learning new tools and strategies for mastering the art and science of teaching." Unfortunately, none of the five participants could mention any magazine on pedagogy that would be of further help to them.

\section{Discussion}

The purpose of this study was to explore the perception of early childhood teacher candidates about their readiness to apply Vygotsky's ZPD in the classroom to promote effective teaching and student engagement after graduation. The research questions focused on the perceptions of the pre-service teachers about their readiness to implement Vygotsky's ZPD in the early childhood classroom when teaching social studies.

The responses from the students to most of the major interview questions about the implementation and application of the ZPD in early childhood classrooms gave a clear indication of their understanding of the process. All of them agreed the application of the ZPD in the early childhood classroom promotes social interaction and effective learning. This observation is supported by findings from others such as Essays, UK (2018) when discussing the application of Vygotsky's theory during the early years of a child's education.

Nevertheless, all the students anticipated problems implementing the ZPD in their social studies classroom. Among the numerous problems they cited included large class size, time, and student behavior. Although the problems they enumerated are clear, in some cases, they should not feel uncomfortable with such issues as group work. It is clear in the early childhood classroom, children by nature do not cooperate very well, teachers should use this background information or developmental stage characteristic to help students learn to share and cooperate to do things in the classroom. As Bekiryazici, (2015) put it "To make the learning environment better, teachers should be careful about grouping the students according to their abilities, not dividing the class into higher-lower 
levels, but rather in a mixed way where every student can learn from each other." (p. 916).

The problems identified by the preservice teachers are like what even many experienced teachers face in most classrooms (Gredler, 2001; Ornstein, \& Sinatra, 2005; Marzano, 2007). The important thing the pre-service teachers or other beginning teachers should know is that the ZPD has logical steps that must be followed if they want to apply the model effectively in the classroom to engage students. Below is the step-by-step process by which a teacher may use to apply the ZPD in the classroom as outlined by Winkler (2019):

- First, a teacher should identify what a student already knows. By identifying this prior knowledge, the teacher can build on that skill when introducing new concepts.

- Next, the teacher can build on this knowledge through scaffolding; the scaffold will help students move from what they already know to what they should know by the end of class. When planning lessons, teachers should keep in mind the scaffolding process by integrating guided practice in their lesson plans.

- Last, teachers can help students connect their new learning to their prior knowledge. For example, if a math teacher has just taught children how to master dividing decimals, the teacher might then relate this concept back to multiplying decimals.

All in all, through the application of the concept of the ZPD, the teacher first identifies what children already know, then teaches them something new to add to it, and then helps the children relate this back to their prior knowledge so that they can now understand the new concept without assistance (Gredler, 2012; Muth, \& Alvermann, 1999). Put succinctly, Farris (2015) argues that children can do things they cannot do on their own but when provided the appropriate assistance from a more knowledgeable person, "they will eventually be able to do successfully all by themselves later." (p. 16).

As clearly pointed out by Slavin (2015) and Woolfolk (2007) the application of the ZPD model in the classroom is not a guarantee that the students will become efficient learners. What the model teaches is that children need guidance from adults or significant others when learning. The model does not support Plato's idea of human beings born with ideas. Like the constructivist view on learning, the model supports John Locke's view of the human brain as being tabular rasa at birth, a blank slate that contains no ideas (Ornstein \& Levine, 2006). It is, therefore, very important that teachers bear this point in mind when applying the ZPD in the lower grades (Gredler, 2012; Muth \& Alvermann, 1999).

As studies continue to demonstrate the implication of the ZPD in the early childhood classroom, (Ehrich, 2006; Verenikina, 2003, 2010) teachers must realize that in order for the ZPD to work effectively, they must "pay careful attention to the levels at which they instruct students as well as the levels of the tasks they ask students to do on their own" (Muth \& Alvermann, 1999, p. 34). Vygotsk's ZPD from the point of view of the pre-service teacher candidates is a 
relevant model for providing scaffolding to support the efforts of students, especially the younger ones, in the classroom to make sense of what they learn (Gredler, 2012).

Above all, this study has made it clear that the days when early childhood teachers did not receive training like the ancient days or during the colonial times in America, today, teaching and learning have assumed new perspectives. Individuals who want to be teachers must be prepared to receive training in both pedagogy and content areas and apply the principles of effective teaching and learning in the classroom in the proper instructional ecology framework (Arends, 2009; Cochran-Smith \& Villegas, 2015; Essa, 2011).

\section{Implications for Future Research}

While this research adds important knowledge to the literature on the preparation of early childhood social teachers, the present findings have implications that could be addressed by further research. One concerns research into the readiness of early childhood preservice social studies teachers to apply integrated social studies content in the classroom. Research into the readiness of early childhood social studies preservice to apply integrated social studies content in the curriculum is important because the extant literature suggests there is a strong correlation between knowledge of content and the application of pedagogical practices (Farris, 2015; Fritzer \& Brewer, 2010; Seefeldt, Castle, \& Falconer, 2014).

Another area worthy of research is the professional development of early childhood social studies preservice teachers. The inability of the participants to identify any professional journal for the social studies appears to be a deficit in their professional preparation, although they were able to identify different tools and resources, they might use to sharpen their professional practice after graduation.

Finally, the present findings indicate classroom management might be a problem for some of the preservice social studies teachers after their graduation. It is therefore important for other scholars to take a critical look at how social studies preservice teachers are prepared to promote effective classroom management when delivering instruction within an effective instructional ecology (Farris, 2015; Fritzer \& Brewer, 2010; Seefeldt, Castle, \& Falconer, 2014).

\section{Limitation}

The sample size for this study was only five preservice early childhood social studies students in the early childhood program in the institution. As already pointed out, these five preservice teachers were part of a larger graduating class of about 30 preservice teachers. The students specialized in different academic areas. Out of the 30 preservice teachers, only five specialized in early childhood education. Teaching social studies methods is one of the courses these students had to complete for the early childhood specialization program. Although the 
qualitative approach to social inquiry makes this small sample size appropriate for the study (Creswell, 2014; White \& McBurney, 2013), the finding from this study may not be generalized to other populations. Additionally, the students were all conveniently selected from one educator preparation provider (EPP) program in the southern region of the United States. It is therefore not recommended that readers apply the findings from this study to other regions with similar EPP programs (McMillan, 2012).

\section{Delimitation}

This study was limited to teacher candidates in only one educator preparation program (EPP) in the southern region of the United States. Though both men and women were included in the study, separate data analyses of the responses to the research questions were based on sex and gender. Additional research with a different research approach such as mixed-methods, region, or sample size, is needed for such analyses (Ary, Jacobs, Sorensen, \& Walker, 2014; Creswell, 2014).

\section{Conclusion}

The discussion about instructional ecology and the application of Vygotsky's ZPD in the classroom were presented within the cognitive construction framework and the research questions. Four conclusions may be drawn from this study. The first is that as educators prepare candidates to enter the teaching profession, they look for theories and pedagogical strategies that are likely to equip the preservice teachers the skills that will help them provide support for student learning within the proper instructional ecology.

The second is that Vygotsky's ZPD has gained universal acceptance as a method of instruction for all grade levels, especially at the lower grades where children need close attention and support from teachers and others who are able to provide clues, structure, or steps for accomplishing specific tasks. Because of this, all major EEPs include a course on Vygotsky's ZPD and other pedagogical approaches in their curriculum for teacher education.

Third, the problems the pre-service teachers perceived may be illusive. The main goal of Vygotsky's ZPD is to promote efficient learning in the classroom. His goal was not to introduce complex and inefficient methods for instructing learners. Perhaps, if Vygotsky had lived long enough to elaborate on his ideas and pedagogical research, he would have provided us answers to these perceived problems. Most of the applications of ZPD in different classrooms as described today in the literature have been created by scholars from their own point of view. As Woolfolk (2007) has put it, “....we don’t even know if Vygotsky would agree with them."

Finally, this study extends our knowledge about the application of Vygotsky's ZPD in the early childhood social studies classroom. As Woolfolk (2007, p. 49) has pointed out, "Sometimes the best teacher is another student who has just 
figured out how to solve the problem, because this student is probably operating in the learner's zone of proximal development." Perhaps, this is a pioneer study in the area of instructional design and application. It is because of this that the findings from this study may not be extended to other situations operating within different instructional ecology.

\section{References}

Arends, R.I. (2009). Learning to teach. Boston, MA: McGraw-Hill Higher Education.

Ary, D., Jacobs, L.C., Sorensen, C.K., \& Walker, D. A. (2014). Introduction to research in education. Belmont, CA: Wadsworth, Cengage Learning.

Bekiryazici, M. (2015). Teaching Mixed-Level Classes with A Vygotskian Perspective. Procedia-Social and Behavioral Sciences, 186, 913 - 917.

Berger, P.L., \& Luckmann, T. (1991). The social construction of reality: A treatise in the sociology of knowledge. England, Penguin Books.

Best, J.W., \& Kahn, J.V. (2006). Research in education. Boston, MA: Pearson.

Bodrova, E. (1997) Key concepts of Vygotsky's theory of learning and development, Journal of Early Childhood Teacher Education, 18:(2), 16-22. doi:10.1080/109010 2970180205

Cochran-Smith, M., \& Villegas, A.M. (2015). Framing teacher preparation research: An overview of the field, part 1, Journal of Teacher Education, 66(1), 7-20.

Cox, C. (2008). Teaching language arts: A student-centered classroom. Boston, MA: Pearson.

Creswell, J.W. (2014). Research design: Qualitative, quantitative, and mixed methods approaches. Los Angeles, CA: Sage.

Davidson, M. (1965). Hellen Keller's teacher. New York, NY: Scholastic Inc.

Driscoll, A., \& Nagel, N.G. (2008). Early childhood education, birth-8: The world of children, families, and educators. Boston, MA: Pearson Education.

Ehrich, J. F. (2006). Vygotskyan inner speech and the reading process. Australian Journal of Educational and Developmental Psychology, 6, 12-25.

Essa, E.L. (2011). Introduction to early childhood education. Belmont, CA: Wadsworth, Cengage Learning.

Essays, UK. (November 2018). Application of Vygotsky's learning theories in early years. Retrieved from https://bit.ly/325YemB.

Farris, P.J. (2015). Elementary and middle social studies: An interdisciplinary, multicultural approach. Long Grove, IL: Waveland Press.

Fritzer, P.J., \& Brewer, E.A. (2010). Social studies content for elementary and middle school teachers. Boston, MA: Allyn \& Bacon.

Glassman, M. (2001). Dewey and Vygotsky: Society, experience and inquiry. Educational Researcher, 30, 3-14. doi:10.3102/0013189X030004003

Goodman, J.F. (2000). Moral education in early childhood: The limits of constructivism, Early Education and Development, 11(1), 37-54.

Gredler, M.E. (2001). Learning and instruction: Theory into practice. Columbus, OH: Merrill Prentice Hall.

Gredler, M.E. (2012). Understanding Vygotsky for the classroom: Is it too late? Educational Psychology Review, 24,113-131.

Henson, K.T. (2004). Constructivist teaching strategies for diverse middle-level classrooms. Boston, MA: Pearson. 
John-Steiner, V, \& Mahn, H. (1996). Sociocultural Approaches to Learning and Development: A Vygotskian Framework. Educational Psychologist, 31(3/4), 191206.

Johnson, J.M. (1975). Doing field research. New York: NY: The Free Press.

Kaplan, L.S., \& Owings, W.A. (2011). American education: Building a common foundation. Belmont, CA: Wadsworth, Cengage Learning.

Kirschner, P.A., John Sweller, J., \& Clark, R.E. (2006). Why Minimal Guidance During Instruction Does Not Work: An Analysis of the Failure of Constructivist, Discovery, Problem-Based, Experiential, and Inquiry-Based Teaching, Educational Psychologist, 41(2), 75-86.

Lantolf, J. P. (2004). Overview of sociocultural theory. In O. S. John, K. van Esch, \& E. Schalkwijk (eds.), New insights in second language learning and teaching (pp. 1334). Frankfurt: Peter Lang Verlag.

Lantolf, J. P. (2008). Sociocultural theory and the teaching of second languages. London: Equinox Publishing.

Larson, B.E., \& Keiper, T.A. (2011). Instructional strategies for middle and secondary social studies: Methods, assessment, and classroom management. New York, NY: Routledge

Lerner, J. (with F. Kline) (2006). Learning disabilities and related disorders: Characteristics and teaching strategies. Boston, MA: Houghton Mifflin Company.

Marzano, R.J. (2007). The art and science of teaching. Alexandria, VA: Association for Supervision and Curriculum Development (ASCD).

Marzano, R. J., \& Brown, J.L. (2009). A handbook for the art and science of teaching. Alexandria, VA: Association for Supervision and Curriculum Development (ASCD).

Maxim, G.W. (2010). Dynamic social studies for constructivist classrooms: Inspiring tomorrow's social scientists. Boston, MA: Allyn and Bacon.

Marginson, S., \& Dang, T.K.A. (2017). Vygotsky's sociocultural theory in the context of globalization, Asia Pacific Journal of Education, 37(1), 116-129, doi: 10.1080/021 88791.2016 .1216827

Mayer, R. E. (2003). Learning and instruction. Upper Saddle River, NJ: Prentice-Hall.

Mayer, R. (2004). Should there be a three-strikes rule against pure discovery learning? The case for guided methods of instruction. American Psychologist, 59(1), 14-19.

McMillan, J.H. (2012). Educational research: Fundamentals for the consumer. Columbus, $\mathrm{OH}$ : Pearson.

McMillan, J.H., \& Schumacher, S. (2006). Research in education: Evidence-based inquiry. Boston, MA: Pearson.

Moore, K.D. (1999). Middle and secondary instructional methods. Boston, MA: McGrawHill

Morrison, G.S. (2012). Early childhood education today. Boston, MA: Pearson.

Muth, K.D., \& Alvermann, D.E. (1999). Teaching and learning in the middle grades. Boston: MA: Allyn and Bacon.

Ornstein, A.C., \& Sinatra, R.C. (2005). Instructional methods: A literacy perspective. Boston, MA: Pearson.

Ornstein, A.C., \& Levine, D.U. (2006). Foundations of education. Boston, MA: Houghton Mifflin Company.

Powell, S.D. (2009). An introduction to education: Choosing your teaching path. Columbus, $\mathrm{OH}$ Pearson.

Ravitch, S.M., \& Carl, N.M. (2016). Qualitative research: Bringing the conceptual, theoretical, and methodological. Thousand Oaks, CA: Sage.

Rubin, H.J., \& Rubin, I.S. (2012). Qualitative interviewing: The art of hearing data. Los Angeles, CA: Sage. 
Rueda, R., \& Yaden, D.B. (2013). The education of young dual-language learners: An overview. In O.N. Saracho (with Spodek, B.) (Eds.), Handbook of research on the education of young children (pp. 157-168). New York, NY, and London; Routledge.

Sanchez, R.M. (2010). The six remaining facts: Social studies content knowledge and elementary preservice teachers. Action in Teacher Education, 32(3), 66-78.

Schickedanz, J.A., Schickedanz, D.I., Forsyth, P.D., \& Forsyth, G.A. (2001). Understanding children and adolescents. Boston, MA: Allyn and Bacon.

Seefeldt, C, Castle, S., \& Falconer, R. (2014). Social studies for the preschool/primary child. Columbus, $\mathrm{OH}$ : Pearson.

Shabani, K. (2016). Applications of Vygotsky's sociocultural approach for teachers' professional development. Cogent Education, 3(1). 1-10.

Slavin, R.E. (2015). Eduational psychology: Theory and practice. Columbus, OH: Pearson.

Snider, M.H., \& Fu, V.R. (1990). The effects of specialized education and job experience on early childhood teachers' knowledge and developmentally appropriate practice, Early Childhood Quarterly, 5, 69-78.

Snowman, J., \& McCown, R. (2015). Psychology applied to teaching. Stamford, CT: Cengage Learning.

Sophian, C. (2013). Mathematics for early childhood education. In O.N. Saracho (with Spodek, B.) (eds.), Handbook of Research on the Education of Young Children (pp. 169-196). New York, NY, and London: Routledge.

Susan, P. (2003). A biographic comparison tracing the origin of their ideas of Jean Piaget and Lev Vygotsky. Retrieved from ERIC database. (ED478987)

Tuckman, B.W., \& Monetti, D. M. (2013). Educational psychology with virtual psychology labs. Belmont, CA: Wadsworth Cengage Learning.

Verenikina, I (2003). Understanding scaffolding and the ZPD in educational research, Proceedings of the International Education Research Conference (AARE - NZARE), 30 November-3 December 2003, Auckland, New Zealand. Retrieved from https:// bit.ly/2vFBzl9.

Verenikina, I. (2010). Vygotsky in twenty-first-century research. In J. Herrington \& B. Hunter (Eds.), Proceedings of World Conference on Educational Multimedia, Hypermedia and Telecommunications (pp. 16-25). Chesapeake, VA: AACE. Retrieved from https://bit.ly/2SDXPES.

Vygotsky, L.S. (1986). Thought and language. Cambridge, MA: MIT Press.

Webb, E.J., Campbell, D.T., Schwartz, R.D., \& Sechrest. (1966). Unobtrusive measures: Nonreactive research in the social sciences. Chicago, IL: Rand McNally College Publishing.

White, T.L., \& McBurney, D.H. (2013). Research methods. Belmont, CA: Wadsworth Cengage Learning.

Winkler, S. (2019). What is the zone of proximal development? Retrieved from https://bit. ly/39IZ9Mn.

Woolfolk, A. (2007). Educational psychology. Boston, MA: Pearson.

Ysseldyke, S. 2004). Assessment in special and inclusive education. Boston, MA: Houghton Mifflin Company.

Zarrillo, J.J. (2012). Teaching elementary social studies: Principles and applications. Columbus, $\mathrm{OH}$ : Pearson. 
